\title{
Effect of Pin Profile on Mechanical Properties of 6061 Al Alloy Welded Joints Prepared by Friction Stir Welding
}

\author{
G.C. Jadhav ${ }^{1}$, Dr.R.S.Dalu ${ }^{2}$ \\ Research Scholar ${ }^{1}$, Department of Mechanical Engineering, Government College of Engineering, Amravati. \\ Professor and I/C Principal ${ }^{2}$, Department of Mechanical Engineering, Government College of Engineering, \\ Sant Gadge Baba Amravati University, Amravati, Maharashtra, India. \\ Email: gc_jadhav31@ rediff.com ${ }^{l}$,rsdalu@ gmail.com ${ }^{2}$
}

\begin{abstract}
The friction stir welding (FSW) is a comparatively innovative solid-state joining process. This joining mechanism is extremely energy efficient, environment friendly and multitalented. The aim of this manuscript is better improvement to the relationship between in the welding parameters and mechanical properties of the aluminum alloy AA6061T-6 type using for the friction stir welding. The effect of the various processing parameters play an important role in the quality of welded joining and the processing parameters are tool rotational speed, traverse speed, axial force and tool geometry play. This paper examine the effect of the tool pin profile and the friction stir welding parameters that on the microstructure and mechanical properties of the aluminum alloy 6061 type for welded join prepared by friction stir welding . It has been establish that prefect grain microstructure is obtained by cylindrical pin profile but they using the square pin profile is a higher strength welded joints are formed.
\end{abstract}

Index Terms- Friction stir welding, 6061 aluminium alloy, tool pin profile, tensile properties.

\section{INTRODUCTION}

The Welding Institute (TWI) of UK had introduced the solid-state joining technique in 1991 and it was initially applied to aluminium alloys. Aluminum alloys are generally classified as nonweldable, because of the poor solidification microstructure and porosity in the fusion zone. Also, the loss in mechanical properties as compared to the base material is very significant. These factors make the joining of these alloys by conventional welding processes unattractive. Some aluminum alloys can be resistance welded, but the surface preparation is expensive, with surface oxide being a major problem. The FSW process utilizes a rotating tool to perform the welding process. The rotating tool consists of small pin (probe) underneath a larger shoulder. The tool serves three primary functions, i.e., heating of the work piece, movement of material to produce the joint and containment below the hot metal tool shoulder. In FSW, rotating shouldered tool plunges into the joining point of plates and the heat is originally developed from the friction between the welding tool (including the shoulder and the probe) and the welded material, which causes the welded material to soften at a temperature less than its melting point. The tool shoulder restricts softened material underneath the shoulder and further leads to movement of material from the front of the pin to the back of the pin by the rotational and transverse movements of tool [5]. It is expected that this process will inherently produce a weld with less residual stress and distortion as compared to the fusion welding methods, since no melting of the material occurs during the welding[6]. Aluminium alloys has a wide range of properties.
Among all, aluminum alloys, AA6061, plays major role in the aerospace industry in which magnesium and silicon $(0.3-1.5 \mathrm{w} \%, \mathrm{Si}, \mathrm{Mg})$ are the principal alloying elements [7]. It is widely used in the aerospace applications, because it has good formability, weldability, machinabilty, corrosion resistance and good strength compared to other aluminum alloys [1, 2, 3]. In Friction Stir Welding, no cover gas or fluxes are used, thereby making the process environmentally friendly, energy efficiency and versatility, since it is a green technology. The joining does not involve any use of filler metal and therefore any aluminum alloy can be joined without concern for the compatibility of composition, which is an issue in fusion welding [4]. He has been attempted to understand the effect of tool pin profiles and rotational speed on FSP zone formation. Also analyses the relations between the FSP zone formation and tensile properties of friction stir welded AA2219 aluminium alloy joints [8]. Evaluate the influence of the process parameters of FSW on the weldments. The Vickers's hardness, tensile strength and radiography are considered for investigation by varying tool speed, feed and maintaining constant depth of penetration of weld and tilt angle [9-10]. The welding equality using FSW depends on the welding parameters like rotational speed, welding speed and applied axial force, during the welding process [12]. Also, the tool shape influences the microstructure and mechanical properties of the welding area. Many researchers studied the effect of pin profile, like cylindrical, square, triangle, etc., on the properties of the welding area. The square pin profile produced more fine grain size on the welding area rather than cylindrical or triangle profiles [13]. It was founded numerically that 
the temperature of the welded zone increases on pin sides. The pin profile has related influence on metal flow [14]. The use of threaded pin profile of tool contributes to better flow of materials between two alloys and the generation of defect free stir zone [15]. In joining dissimilar materials, hexagonal pin profile produced a superior strength joints compared by triangle pin profile [16]. However, the pin profile affects both the temperature of the welding area and the material flow, during welding process. In this investigation, an attempt was made to study the effect of tool geometry (cylindrical, square, and triangular) and parameters on mechanical properties and weld quality.

\section{EXPERIMENTAL PROCEDURE}

The investigational processes for demeanor experimentation are given below.

\subsection{Material}

The aluminum AA6061-T651 compound with the measure of $100 \mathrm{~mm}$ long and $82 \mathrm{~mm}$ in width and the $6.3 \mathrm{~mm}$ in thickness these materials are utilized in the examination think about. The mechanical composition of aluminum alloy AA 6061are given below in Table 1.

Table 1: Mechanical properties

\begin{tabular}{|c|c|c|c|c|}
\hline $\begin{array}{c}\text { Name of } \\
\text { the } \\
\begin{array}{c}\text { Aluminum } \\
\text { alloy }\end{array}\end{array}$ & $\begin{array}{c}\text { Yield } \\
\text { strength } \\
\text { in } \mathrm{MPa}\end{array}$ & $\begin{array}{c}\text { Ultimate } \\
\text { strength } \\
\text { in MPa }\end{array}$ & $\begin{array}{c}\text { Elong } \\
\text { ation } \\
\%\end{array}$ & $\begin{array}{c}\text { Hard } \\
\text { ness } \\
\text { in } \\
\mathrm{HV}\end{array}$ \\
\hline AA 6061 & 110 & 207 & 16 & 75 \\
\hline
\end{tabular}

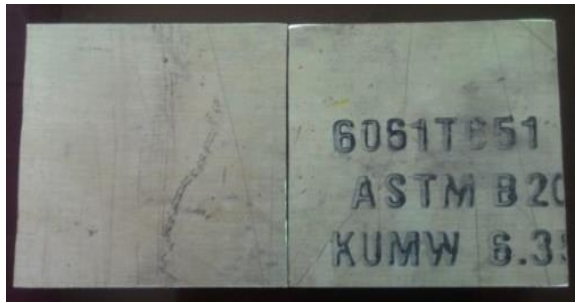

Fig. 1: Aluminium Alloy plates

The AA6061 Aluminum alloy is one of the major broadly utilized amalgams in the 6000 arrangement. The AA6061 aluminum alloy is the primarily versatile for the warmth treatable amalgam. This aluminum composite primarily utilized in airplane industry and car parts processing plants for the yatch development, etc. The figure 1 demonstrates the work bit of material utilized in Friction stir welded (FSW) procedure.

\subsection{Welding Tools}

For this The cylinder shaped, square and triangular FSW instruments are intended for this trial. The D2 steel is accustomed to making the FSW device. The distinctive apparatuses are utilized to play out the FSW joints. The FSW joints have the test shapes like chamber, square, triangular. That will be appear in figure 2 and the FSW tool measurements are referenced in the table 2.
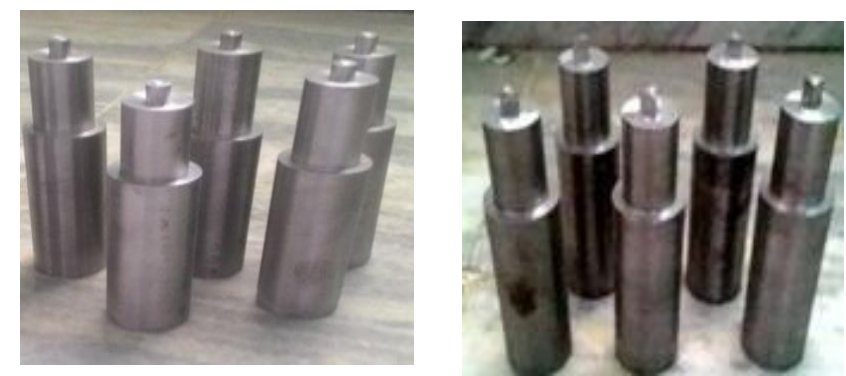

Fig. 2: Cylindrical, square and triangular FSW tools

Table 2: Tool Dimensions

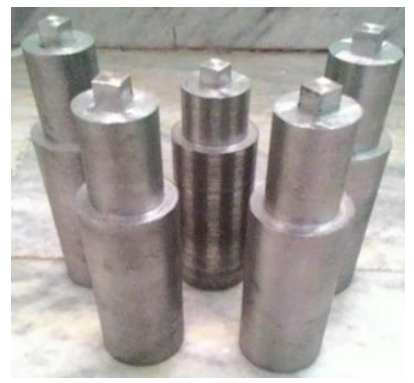

\begin{tabular}{|l|l|}
\hline Specifications & Values \\
\hline Length of Tool & $70 \mathrm{~mm}$ \\
\hline $\begin{array}{l}\text { Tool Shoulder } \\
\text { Diameter }\end{array}$ & $16,17,18,19,20 \mathrm{~mm}$ \\
\hline Pin Diameter & $6 \mathrm{~mm}$ \\
\hline Pin Length & $4.2 \mathrm{~mm}$ \\
\hline Tool Profile & $\begin{array}{l}\text { Cylindrical, } \\
\text { Triangular }\end{array}$ \\
\hline
\end{tabular}

\subsection{Frictions stir welding on universal Milling} machine with vertical attachment

To finish the procedure of Friction stir welded utilize the general preparing machine (Model BFU-5). The FSW methodology gives the primary significance to the fifty bits of AA6061 aluminum alloy type. It having the measure of $100 \times 82 \times 6 \mathrm{~mm}$ this is the set up purpose behind Friction stir welded strategy. The FSW strategy utilizes the Butt-welded method for the two rectangular plates in the above size. The conventional vertical handling machine was utilized for the grinding mix welding method by utilizing the one of a kind establishment. This component solidly fixed on the preparing strategy table to be kept on the vibration from happening it as a result of the frictional forces of the welding technique. The Taguchi perfect plan is constantly used to investigation the amounts of the system. The vertical association and machine handling are as emerge in the figure 3 . 


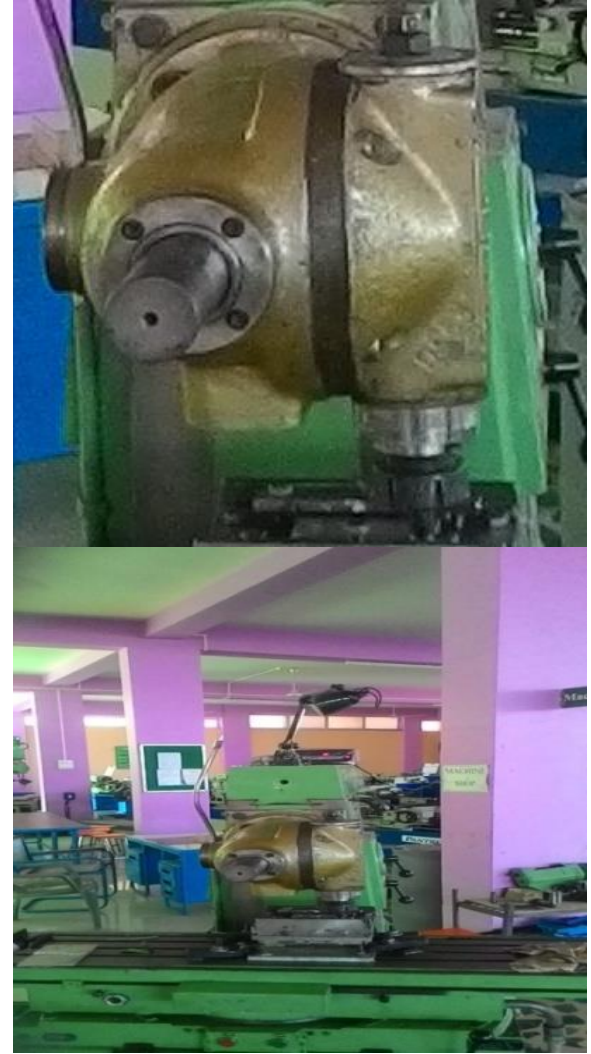

Fig. 3: Vertical attachment and milling machine

\subsection{Working level of process parameters.}

We have been choosing five processing parameters from the literature survey, arrangement of the obtainable universal milling machine and tool pin diameter. The length of these tools keeps as a constant for the experimental by using the Taguchi design. And the $\mathrm{L}_{25}$ Orthogonal array is used to the demeanor experiments . They has three FSW tool profiles have been studied. The three pins profiles are (a) cylindrical (b) square and (c) triangular shapes were used in this experimental. All the pins are cut from a cylindrical shape of $6 \mathrm{~mm}$ diameter and $4.2 \mathrm{~mm}$ in height and this kept constant. Welding parameters used in experimentation is as shown in Table 3
Table 3: Welding parameters used in experimentation

\begin{tabular}{|l|l|}
\hline $\begin{array}{l}\text { Process } \\
\text { parameters }\end{array}$ & Values \\
\hline $\begin{array}{l}\text { Rotational } \\
\text { speed }\end{array}$ & $500,710,1000,1400,2000 \mathrm{rpm}$ \\
\hline $\begin{array}{l}\text { Welding } \\
\text { speed }\end{array}$ & $14,20,28,40,56 \mathrm{~mm} / \mathrm{min}$ \\
\hline Axial force & $5,6,7,8,9 \mathrm{kN}$ \\
\hline $\begin{array}{l}\text { Tool } \\
\text { material }\end{array}$ & D2 Steel \\
\hline $\begin{array}{l}\text { Tool } \\
\text { dimensions }\end{array}$ & $\begin{array}{l}\text { Shoulder diameter: } 16,17,18,19, \\
20 \text { mm } \\
\text { Pin diameter: } 6 \mathrm{~mm} \text { and pin length } \\
4.2 \mathrm{~mm} . \\
\text { Tool pin profiles: } \\
\text { Straight cylindrical, triangular, } \\
\text { square }\end{array}$ \\
\hline $\begin{array}{l}\text { Tool tilt } \\
\text { angle }\end{array}$ & $0,1,1.5,2,3$ degree \\
\hline
\end{tabular}

\subsection{Tensile specimen}

Transverse tensile test samples were prepared from weld joints, according to the ASTM specifications E8M-08 [ASTM-2008], as shown in Figure 4. Tensile test and metallographic pieces were prepared from each weld joints. Size of metallographic plate is $10 \mathrm{x}$ $30 \mathrm{~mm}$.
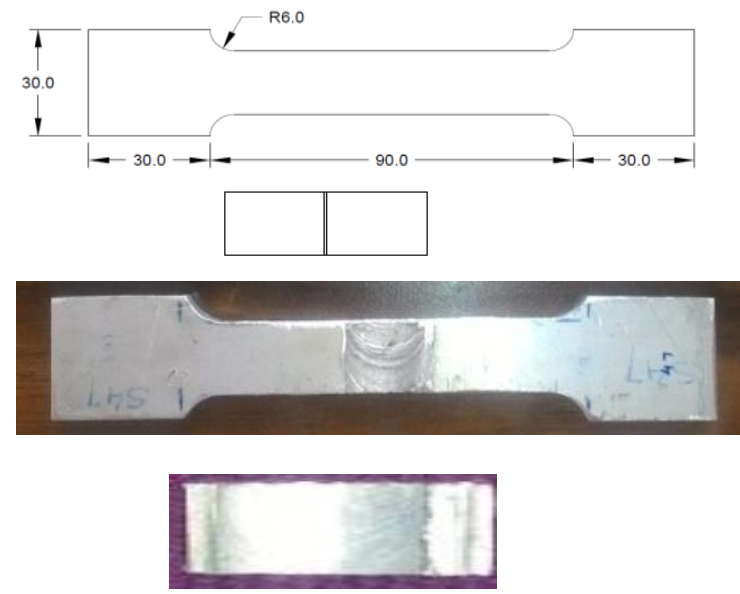

Fig. 4: Tensile test and metallographic specimen 
International Journal of Research in Advent Technology, Vol.7, No.4, April 2019

E-ISSN: 2321-9637

Available online at $w w w . i j r a t . o r g$

2.6. Pin profile:

\begin{tabular}{|l|l|l|l|l|l|}
\hline Pin profile & Dimensions & $\begin{array}{l}\text { Area occupied } \\
\text { by pin in static } \\
\text { condition }\end{array}$ & $\begin{array}{l}\text { Pin } \\
\text { volume } \\
\mathbf{m m}^{\mathbf{3}}\end{array}$ & $\begin{array}{l}\text { Swept } \\
\text { volume } \\
\mathbf{m m}^{\mathbf{3}}\end{array}$ & $\begin{array}{l}\text { Swept } \\
\text { volume/ } \\
\text { volume }\end{array}$ \\
\hline pin
\end{tabular}

\section{RESULTS AND DISCUSSION}

\subsection{Microstructure}

The microstructure development of the welding zone are influenced basically by 2 parts, viz., the first issue is that the temperature that depends upon the speed distinction between the heat created and warmth distributed, amid the welding procedure. The second issue is plastic distortion, incited by the blending activity. during this examination, the welded examples cooled commonly by air, wherever the heat made is forced by the welding procedure as move speed, welding speed, the important power and also the shoulder distance across.

The stick profile assumes a principle job within the quantity of metal twisted amid welding. The optical microstructure of the bottom metal and also the combine zone of the welded elements delivered by numerous stick profiles are appeared in Fig. 5(a) the blending zone has encountered high temperatures and broad plastic miss sharpening and is depicted by powerfully re-crystallized grains. Fine equaled grain structure was gained within the combine zone. The stick profile influences the mix zone microstructures very. Fig.5 (b) demonstrates a fine equaled grain microstructure, gotten by tube formed stick profile. Whereas utilizing a triangle stick profile led to a delayed grain microstructure thanks to all the lot of throbbing rate and expulsion happened to metal amid mixing is appeared in Fig. 5(d). The grains within the combine zone encounter high temperatures and violent material stream conveyance regarding serious plastic miss happening. Very fine grains are formed thanks to increasingly re-crystallization contrasted with weld combine zone created with sq. stick profile as appeared in Fig. 5(c). From small structural changes and consequences of mix zone dimension, it's clearly incontestable that the microstructure of the welded zone is dependent on the device stick profile and also the welding parameters.

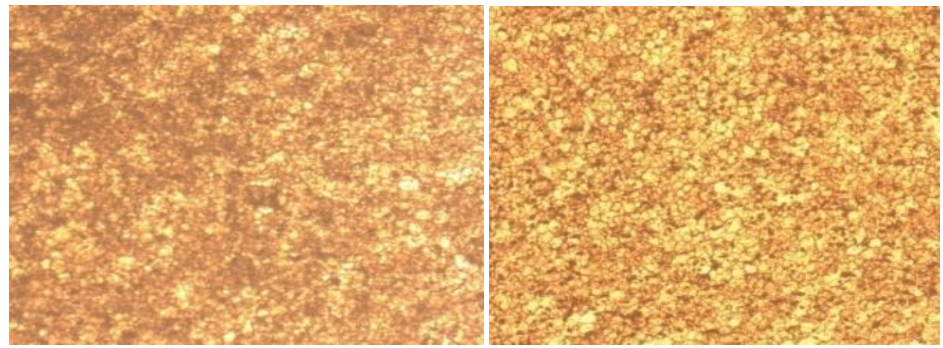

(a)

(b) 


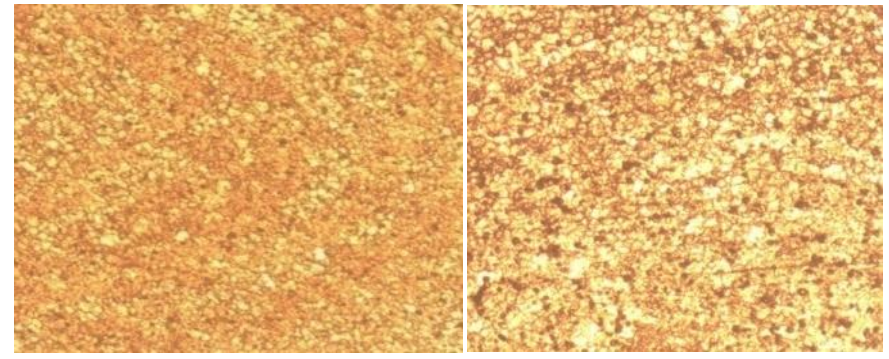

(c) (d)

Fig. 5: Microstructure of a) base metal and welding zone produced by b) cylindrical, c) square, d) triangle.

\subsection{Mechanical Properties}

Transverse tractable properties of FSW joints are assessed. The standard of the joints organized by triangular profile includes a higher extreme physical property checked out than the opposite 2 stick profiles. The foremost noteworthy extreme rigidity saw at 710 speed rate and twenty $\mathrm{mm} / \mathrm{min}$, axial force seven $\mathrm{kN}$, three tilt purpose and shoulder diameter nineteen millimeter for mix zone, created by triangular stick profile than by sq. and therefore the least esteem no heritable for joints delivered by spherical and hollow stick profile. This outcome coordinated with the outcomes no heritable by past scientists. This can be on the grounds that the triangular stick has most elevated shoulder region, therefore it creates adequate heat for welding of on top of parameters and produces imperfectness free joint.

Deformities found in every square and triangular profile are given in table no.5 and 6 on an individual basis.

Table 5: Defects found in square profile with respect to tensile strength.

\begin{tabular}{|l|l|l|l|l|l|l|l|l|l|l|l|l|l|l|}
\hline $\begin{array}{l}\text { Defects } \\
\text { type }\end{array}$ & S32 & S31 & S41 & S29 & S30 & S39 & S36 & S38 & S37 & S27 & S48 & S47 & S26 & S33 \\
\hline $\begin{array}{l}\text { Warm } \\
\text { hole }\end{array}$ & & & & & & $\sqrt{ }$ & & & & & & $\sqrt{ }$ & & \\
\hline Crack & & & & & & $\sqrt{ }$ & & & & & & $\sqrt{ }$ & $\sqrt{ }$ & \\
\hline Tunnel & & & & $\sqrt{ }$ & & & & & & & & & $\sqrt{ }$ & \\
\hline Voids & & & & & & & & & & & & & & \\
\hline $\begin{array}{l}\text { Tensile } \\
\text { strength }\end{array}$ & 0.255 & 0.240 & 0.236 & 0.232 & 0.230 & 0.225 & 0.215 & 0.212 & 0.201 & 0.201 & 0.182 & 0.182 & 0.175 & 0.168 \\
\hline
\end{tabular}

Table 6: Defects found in triangular profile with respect to tensile strength.

\begin{tabular}{|l|l|l|l|l|l|l|l|l|l|l|l|l|l|l|}
\hline $\begin{array}{l}\text { Defects } \\
\text { type }\end{array}$ & S57 & S55 & S66 & S64 & S56 & S63 & S54 & S53 & S62 & S52 & S73 & S59 & S68 & S70 \\
\hline $\begin{array}{l}\text { Warm } \\
\text { hole }\end{array}$ & & & & & & & & & & $\sqrt{ }$ & & & $\sqrt{ }$ & \\
\hline Crack & & & & & & & & & & $\sqrt{ }$ & & $\sqrt{ }$ & & $\sqrt{ }$ \\
\hline Tunnel & & & & & & & & & & & & & $\sqrt{ }$ & \\
\hline Voids & & & & & & & & & & & & & & $\sqrt{ }$ \\
\hline $\begin{array}{l}\text { Tensile } \\
\text { strength }\end{array}$ & 0.345 & 0.305 & 0.301 & 0.289 & 0.288 & 0.285 & 0.285 & 0.279 & 0.272 & 0.253 & 0.251 & 0.245 & 0.236 & 0.232 \\
\hline
\end{tabular}




\section{E-ISSN: 2321-9637}

\section{Available online at www.ijrat.org}

\subsubsection{Microstructures Of FSW Defects Found In Square And Triangular Profile:}

Few defects are shown for square and triangular profile in figure 6.

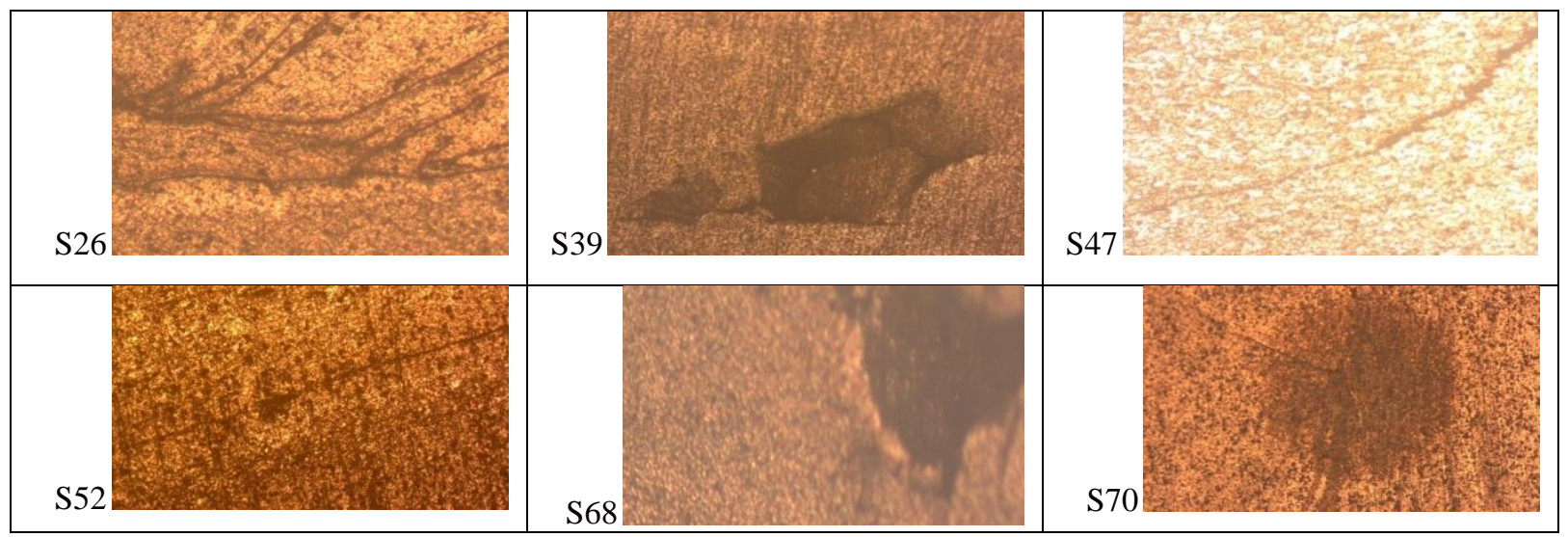

\section{CONCLUSION}

In the present investigation, the impact apparatus stick profile and welding process on contact blend welding of AA 6061 amalgam was considered and dependent on the outcomes, the accompanying ends can be drawn:

1. The quality of the joints arranged by triangular stick profile has a higher extreme rigidity contrasted with that delivered by barrel shaped and square stick profiles.

2. The most elevated extreme rigidity, 0.255 $\mathrm{kN} / \mathrm{mm}^{2}$ saw at $710 \mathrm{rpm}, 20 \mathrm{~mm} / \mathrm{min}$, axial power $7 \mathrm{kN}$, shoulder diameter $19 \mathrm{~mm}$ and tilt angle $3^{0}$ for blend zone created by square stick profile.

3. Ultimate tensile strength, $0.345 \mathrm{kN} / \mathrm{mm}^{2}$ acquired by triangular solid profile is at parameters $710 \mathrm{rpm}, 20 \mathrm{~mm} / \mathrm{min}, 7 \mathrm{kN}, 19 \mathrm{~mm}$ and $3^{0}$.

4. Defects are found due to insufficient stirring, low heat input, inadequate material mixing and an improper formation of dynamically recrystallized zone. This happen due to improper selection of performance parameters. Tensile strength decreases with increase in the defects found in joints.

\section{Acknowledgments}

The creators are appreciative to the Visvesvaraya National Institute of Technology, Department of Metallurgical and Material Engineering, Nagpur, India, for broadening the offices of Material Testing Laboratory to complete this examination.

\section{REFERENCES}

[1] Thomas WM; Nicholas ED; Needham JC; Murch MG; Temple-Smith P; Dawes CJ. (1991): Friction stir butt welding. International Patent Application No. PCT/GB92/02203.
[2] M.Ecomoto(2003):Friction Stir Welding : Research and industrial applications. Welding International, 17(3), pp. 341-345.

[3] Thomas WM (2003): Friction stir welding recent developments. Mater Sci. Forum, 426432:229-36.

[4] R.S. Mishra; Z.Y. Ma (2005): Friction stirs welding and processing. Materials Science and Engineering R, 50, pp. 1-78.

[5] Singh R. K. R.; Sharma C.; Dwivedi D. K.; Mehta N. K.; Kumar P. (2011): The microstructure and mechanical properties of friction stir welded $\mathrm{Al}-$ $\mathrm{Zn}-\mathrm{Mg}$ alloy in as welded and heat treated conditions. Materials and Design, 32, pp. 682687

[6] G. Cam; (2013): Friction stir welded structural materials: beyond Al-alloys, International Materials Reviews. 56, pp.1-48.

[7] Indira Rani M; Marpu R.N ; A.C.S. Kumar ( 2011):_A study of process parameters of friction stir welded AA6061 aluminium alloy in o and $\mathrm{t}-6$ conditions. APRN Journal of Engineering and Applied Science Engineering. 6(2), pp. 61-66.

[8] K. Elangovan; V. Balasubramanian (2007): Influences of pin profile and rotational speed of the tool on the formation of friction stir processing zone in AA2219 aluminium alloy. Materials Science and Engineering. A 459, pp. $7-$ 18 .

[9] Z. Barlas ; U. Ozsarac (2012):Effects of FSW Parameters on Joint Properties of AlMg3 Alloy Welding Journal, 91(1), 16s-22s.

[10] Ahmed Khalid Hussain;Syed Azam Pasha Quadri(2010): Evaluation of parameters of friction stir welding for aluminium AA6351 alloy. International Journal of Engineering Science and Technology, 2(10), pp. 5977-5984.

[11] Phillip J. Ross (2005): Taguchi Techniques for Quality Engineering. McGraw Hill Education 
International Journal of Research in Advent Technology, Vol.7, No.4, April 2019

E-ISSN: 2321-9637

Available online at www.ijrat.org

(India) Private Limited, New Delhi, Second Edition

[12] S. M. Bayazid; H. Farhangi; A. Ghahramani; (2015): Effect of pin profile on defects on friction stir weld 7075 aluminum alloy. Procedia material science, 11, pp.12-16.

[13] M. Mehta;G.M. Reddy; A.V. Rao; A. De (2015): Numerical modeling of friction stir welding using the tools with polygonal pins. Defence Technology, 11, pp. 229-236.

[14]M. Elangovan; S. Rajendra Boopathy; V. Balasubramanian (2015): Effect of tool pin profile on microstructure and tensile properties of friction stir welded dissimilar AA 6061 -AA5086 aluminum alloy joints. Defence Technology, 11, pp. 174-184.

[15] Sabeerushen; J.R. Vinod Kumar (2016): Influence of tool pin profile on the tensile behavior of dissimilar friction stir welded joints of aluminum alloys. Int. J. of Innovative Research in Science, Engineering and Technology, 5, pp. 5376-5382.

[16] J. Hodowany; G. Ravichandran; A.J. Rosakis, P. Rosakis (2000): Partition of plastic work into heat and stored energy in metals. Exp. Mech., 40(2), pp. 113-123. 